\title{
Challenges of Tunnelling in Volcanic Rock Masses
}

\author{
Marlène C. Villeneuve \\ Chair of Subsurface Engineering, Montanuniversität Leoben, Leoben, Austria
}

Received October 24, 2021; accepted November 12, 2021; published online November 30, 2021

\begin{abstract}
Volcanic rock masses exhibit temporal and spatial variability, even at the scale and duration of engineering projects. Volcanic processes are dynamic, resulting in rock masses ranging from high-porosity, clay-rich, fractured, and soil-like to low-porosity, high-strength, brittle, and massive. Based on a number of studies in a variety of geological settings, such as active and fossil geothermal systems, on the surface of active volcanoes and up to $3000 \mathrm{~m}$ below the surface, the work presented in this article shows the relationship between geological characteristics and mechanical parameters of volcanic rocks. These are then linked to the resultant challenges to tunnelling associated with the mechanical behaviour of volcanic rocks and rock masses, ranging from ductile failure such as squeezing and swelling to dynamic failure such as spalling and rockburst.

This article highlights some of the key parameters that should be incorporated in site and laboratory investigations to build representative ground models in volcanic rocks and rock masses. Rock mass characterisation needs to address the highly variable and anisotropic nature of volcanic rocks, ranging from millimetre to decametre scale. Ground models must include not only the mechanical properties, such as strength and stiffness, of typical lab investigations, but also petrophysical properties, such as porosity, and geological conditions, such as alteration. Geomechanical characterisation of these rock masses requires an understanding of geological processes to select appropriate field, lab and design tools. In volcanic rocks, perhaps more than any other rock types, the geology is critical to characterising and understanding the behaviour in response to tunnelling.
\end{abstract}

Keywords: Rock mechanics, Porosity, Lab testing, Deformation, Characterisation

\footnotetext{
M. C. Villeneuve ( $\square)$

Chair of Subsurface Engineering,

Montanuniversität Leoben,

Franz Josef Straße 18,

Leoben, Austria

marlene.villeneuve@unileoben.ac.at
}

Herausforderungen beim Tunnelbau in vulkanischem Gestein

Zusammenfassung: Vulkanische Gesteinsmassen weisen eine zeitliche und räumliche Variabilität auf. Vulkanische Prozesse sind dynamisch und führen zu Gesteinsmassen, die von hochporösem, tonreichem, zerklüftetem und erdähnlichem bis hin zu niedrigporösem, hochfestem, sprödem und massivem Gestein reichen. Auf der Grundlage einer Reihe von Studien in verschiedenen geologischen Umgebungen, zeigt die in diesem Artikel vorgestellte Arbeit die Beziehung zwischen geologischen Merkmalen und mechanischen Parametern von Vulkangestein. Diese werden dann mit den sich daraus ergebenden Herausforderungen für den Tunnelbau in Verbindung gebracht, die mit dem mechanischen Verhalten vulkanischer Gesteine und Gesteinsmassen verbunden sind.

Schlüsselwörter: Felsmechanik, Porosität, Laborversuche, Verformung, Charakterisierung

\section{Characteristics of Volcanic Rocks and Rock Masses}

It is reasonably well understood that composition and texture will affect rock physical and mechanical properties (e.g. [1]). Because of the dynamic systems in which volcanic rock masses are typically generated (Fig. 1), composition and texture are highly spatially and temporally variable, with interplay between primary composition and texture, as well as external processes, leading to a variety of different secondary compositions and textures (Fig. 2). In hydrothermal systems, often associated with volcanic environments, the temperature of the hydrothermal fluids plays a key role in the type of alteration, and hence the porosity and secondary mineralisation, that will occur (Fig. 3). Alteration can affect porosity by infilling pores and fractures as well as dissolving primary minerals [2], leading to high compositional and textural variability.

This macro-scale variability is associated with variability in the mechanical properties of volcanic rocks, in partic- 


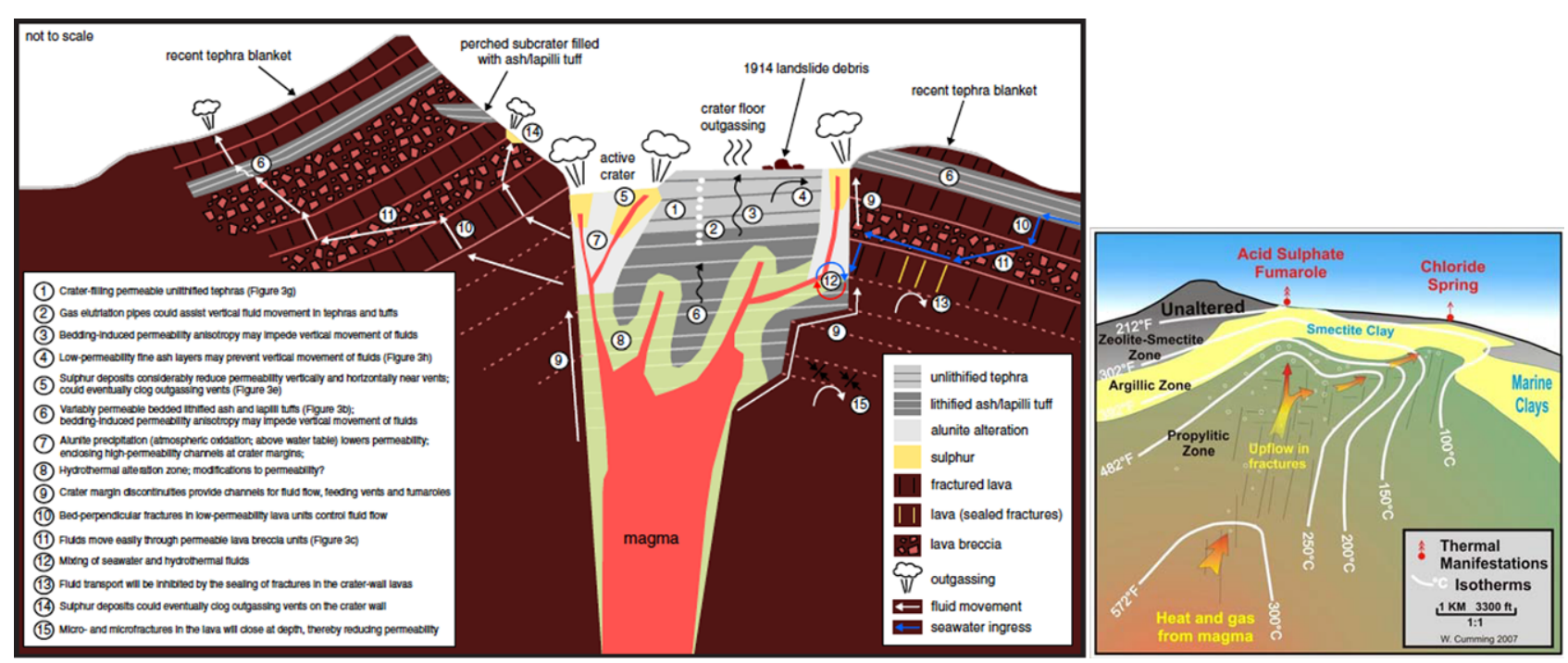

Fig. 1: Example2-Dschematics-ageological ground model showing material properties and volcanic and hydrological processes in Whakaarivolcano, New Zealand [3]; b Conceptual model of a conventional, hot, liquid dominated geothermal field. The model has been split into the alteration zones typical for a geothermal field, with temperature profiles and surface expressions [4]. Smectitic alteration refers to low temperature alteration dominated by smectite clays, while propylitic alteration refers to high temperature alteration dominated by chlorite, epidote and quartz. Argillic alteration occurs between the two, and is also clay dominated, but in this case with illite clays
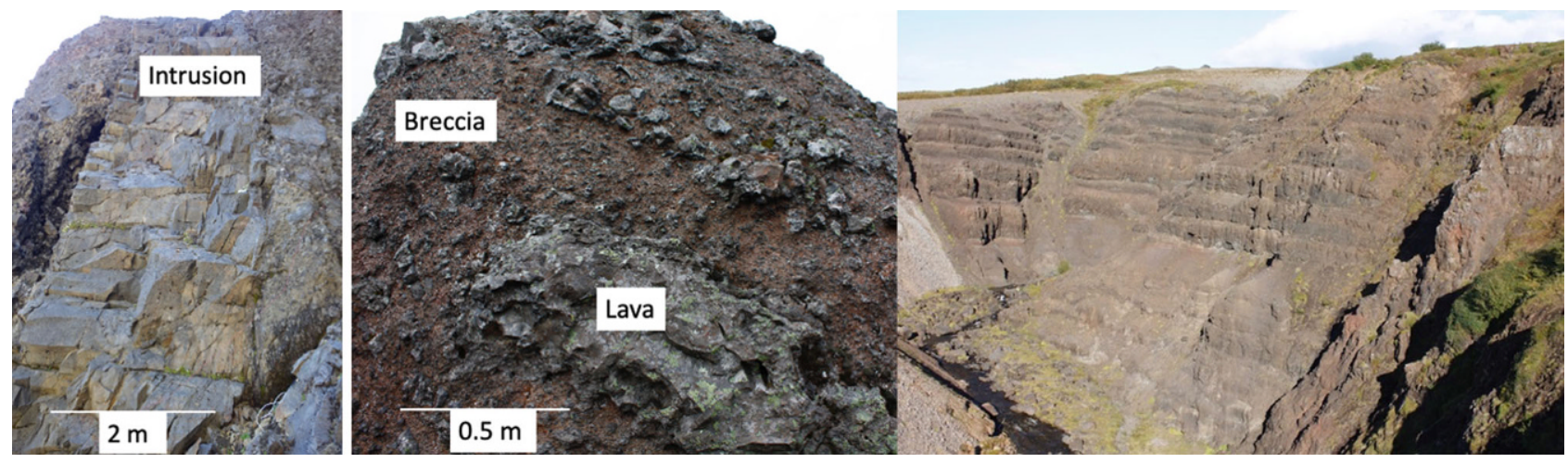

Fig. 2: Examples ofvolcanictextures; a outcropscale dense andesitedyke unaltered intrusion(UI) into variably density andesite lavaflows, Mt. Ruapehu, NewZealand; b outcrop scale basalt showing unaltered dense coherent lava (DCL) and brecciated lava margins (BLM) consisting of lava blocks in a matrix with higher porosity, Iceland; c edifice scale anisotropy in Icelandic basalt lava flows

ular with respect to differences in porosity and secondary mineralogy associated with alteration. Porosity describes the proportion of voids in a rock, and for a similar mineralogy, porosity will have a direct relationship with density. The presence of pore (connected and not connected) negatively impacts uniaxial compressive strength (Fig. 4) and Young's modulus (Fig. 5), two of the key mechanical parameters used for excavation design. These two relationships are well established in the rock physics and rock mechanics literature, as highlighted by [6]. Both relationships show high variability, which demonstrates that, while porosity is important, it is not the only characteristic affecting these parameters. The variability is particularly high at low porosity, suggesting that, at low porosity, the other geological characteristics are more important than porosity. Conversely, Poisson's ratio is not sensitive to porosity [7].

While the elastic moduli and intact compressive strength are important for tunnel design using analytical techniques, numerical modelling of tunnel behaviour requires full fail- ure criteria, such as Mohr-Coulomb or Hoek-Brown. The failure criteria are also highly dependent on the texture, porosity and alteration of volcanic rocks (Fig. 6). To build failure criteria, the Hoek-Brown parameter, $\mathrm{m}_{\mathrm{i}}$, and/or the Mohr-Coulomb parameters, cohesion and friction angle, are derived from curve-fitting the failure criterion to triaxial test data [11]. Triaxial testing is not always possible during site investigation for tunnel design and the Hoek-Brown parameter $\mathrm{m}_{\mathrm{i}}$, which controls the steepness and curvature of the failure envelope, is often extracted from tables in the literature [12]. demonstrate that the commonly used tabulated $m_{i}$ values (e.g. those based on Hoek and Brown, 1997 [11]) fail to capture the wide variability in these values, especially in volcanic rocks. Read and Richards (2011) [12] also highlight that different $m_{i}$ will result in vastly different failure criteria even with the same intact uniaxial compressive strength (Fig. 7). [13] and [14] provide transfer functions to estimate $\mathrm{m}_{\mathrm{i}}$, as well as cohesion and friction angle, in the 


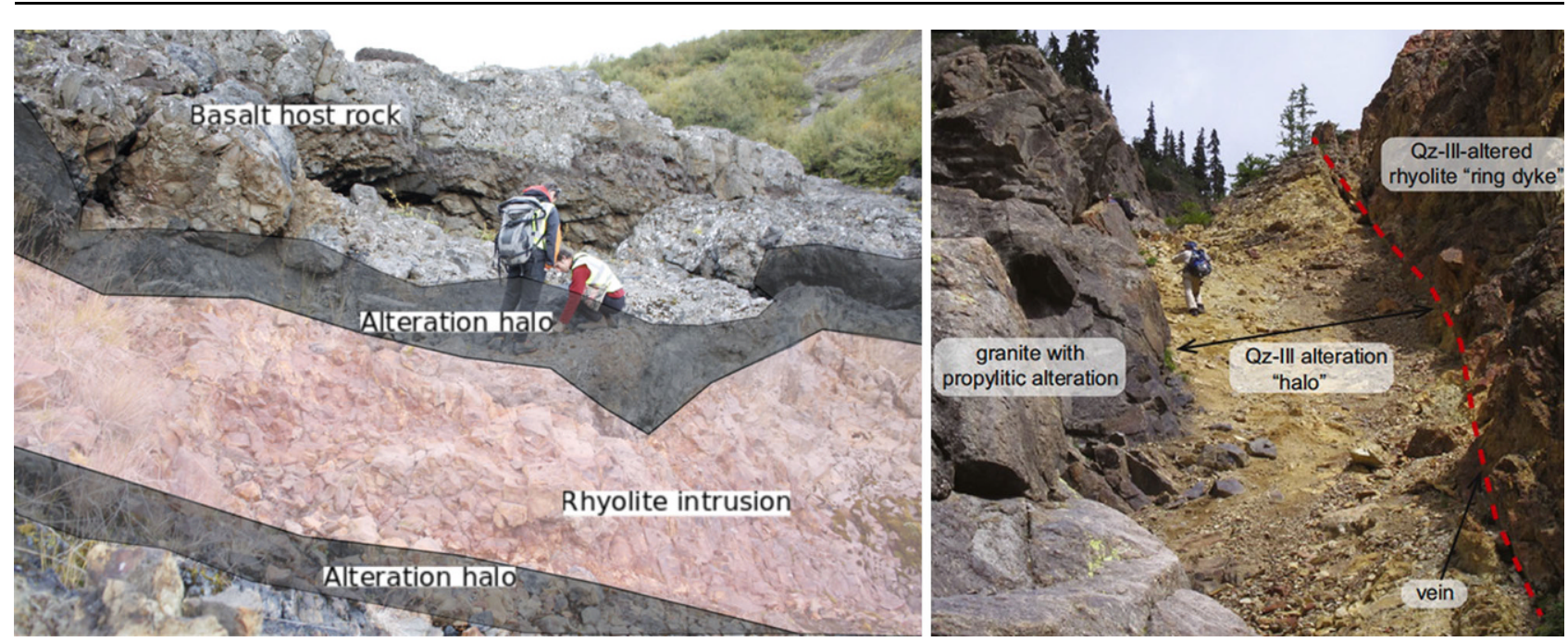

Fig. 3: Example alteration halos at contacts between: a a rhyolite intrusion (red) and basalt (dark grey) with an alteration halo (black) between them, Barnafossar, Húsafell, Iceland; (right) Alteration halo composed of secondary mineralogy (leftand centre) associated with hot fluids adjacent to primary mineralogy $\mathbf{b}$ in rhyolite dyke, Lake City Caldera, USA [5]
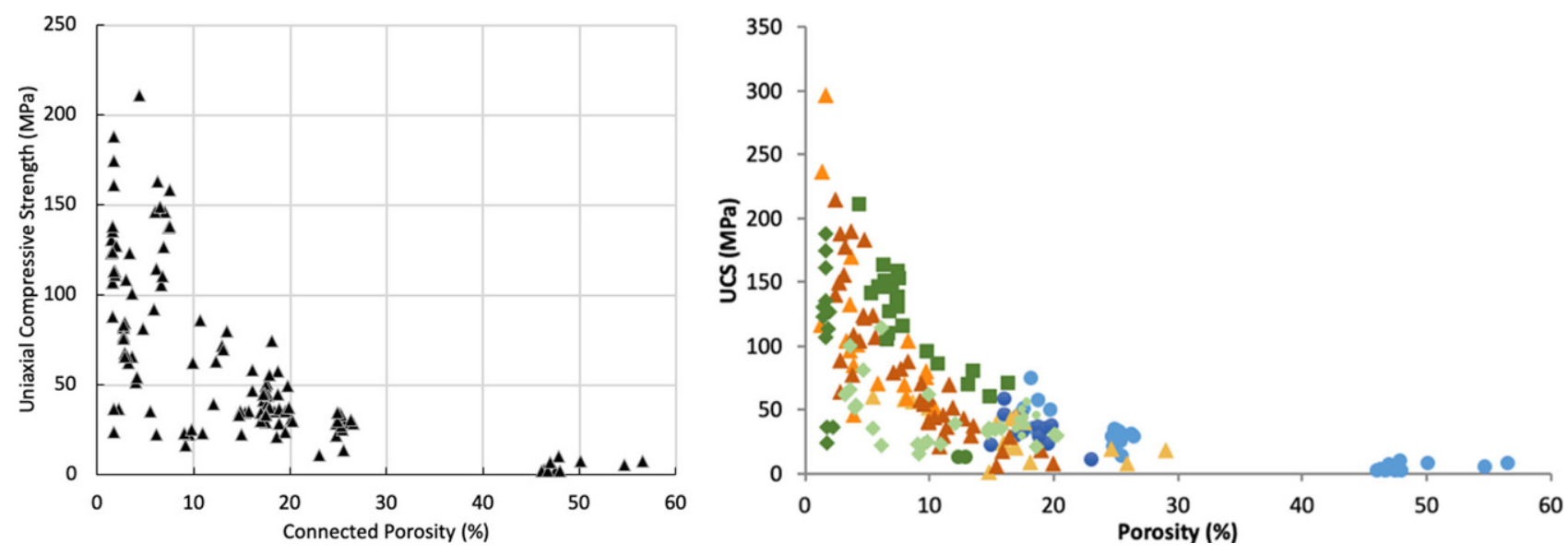

Fig. 4: Uniaxial compressive strength versus porosity a for volcanics from the Taupō volcanic zone (modified from [8]; and b Impact of alteration on the porosity-UCS relationships [9]
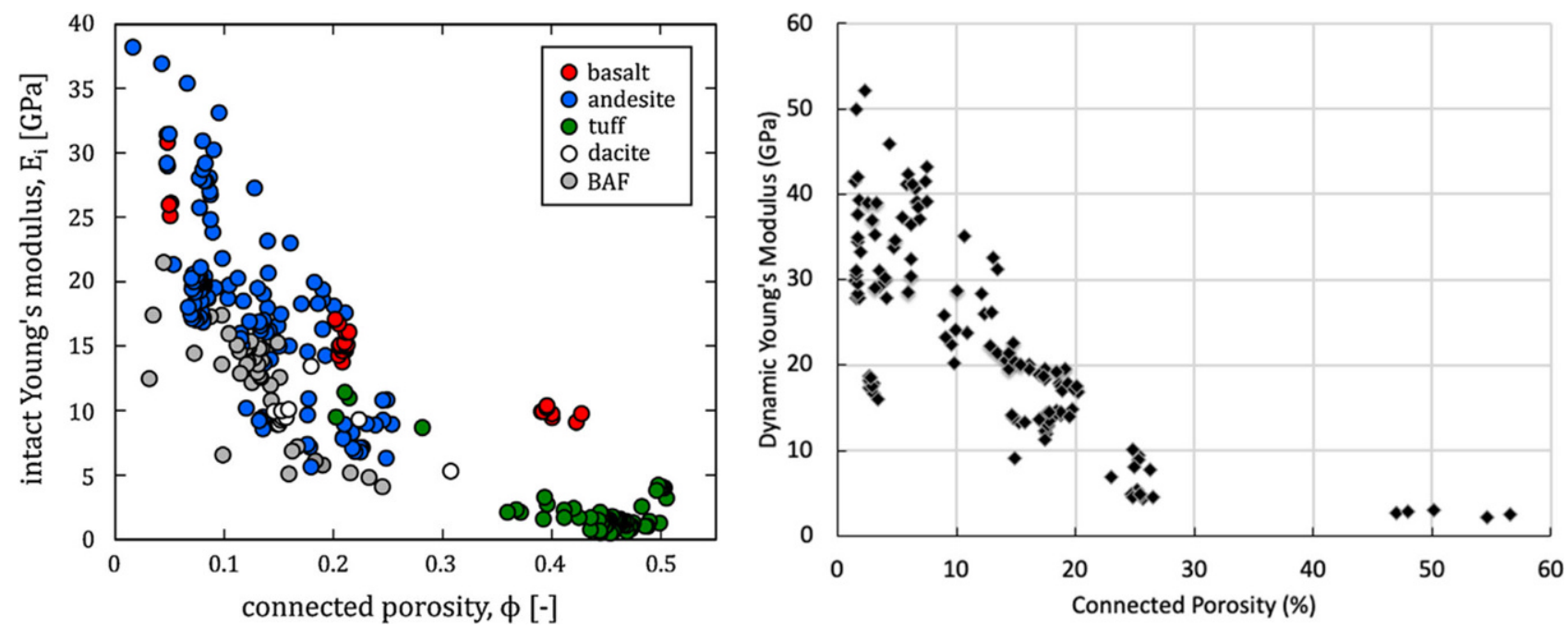

Fig. 5: Relationships between connected porosity and Young's modulus in a variety of volcanic rock types; a static modulus (BAF-block and ash flow [7]), b dynamic modulus from seismic wave velocities (based on data from [10] and [8]) 
Fig. 6: Effect of alteration and porosity on the Hoek-Brown failure criteria for three different andesite textures (modified from [15]). UBLM unaltered brecciated lava margin (high porosity), $A B L M$ altered brecciated lava margin (moderate porosity), UDCL unaltered dense coherent lava (very low porosity), $A D C L$ altered dense coherent lava (moderate porosity), Ulunaltered intrusion (very low porosity), Alaltered intrusion (low porosity), arrows show the change in the failure criterion from the unaltered to the altered rock

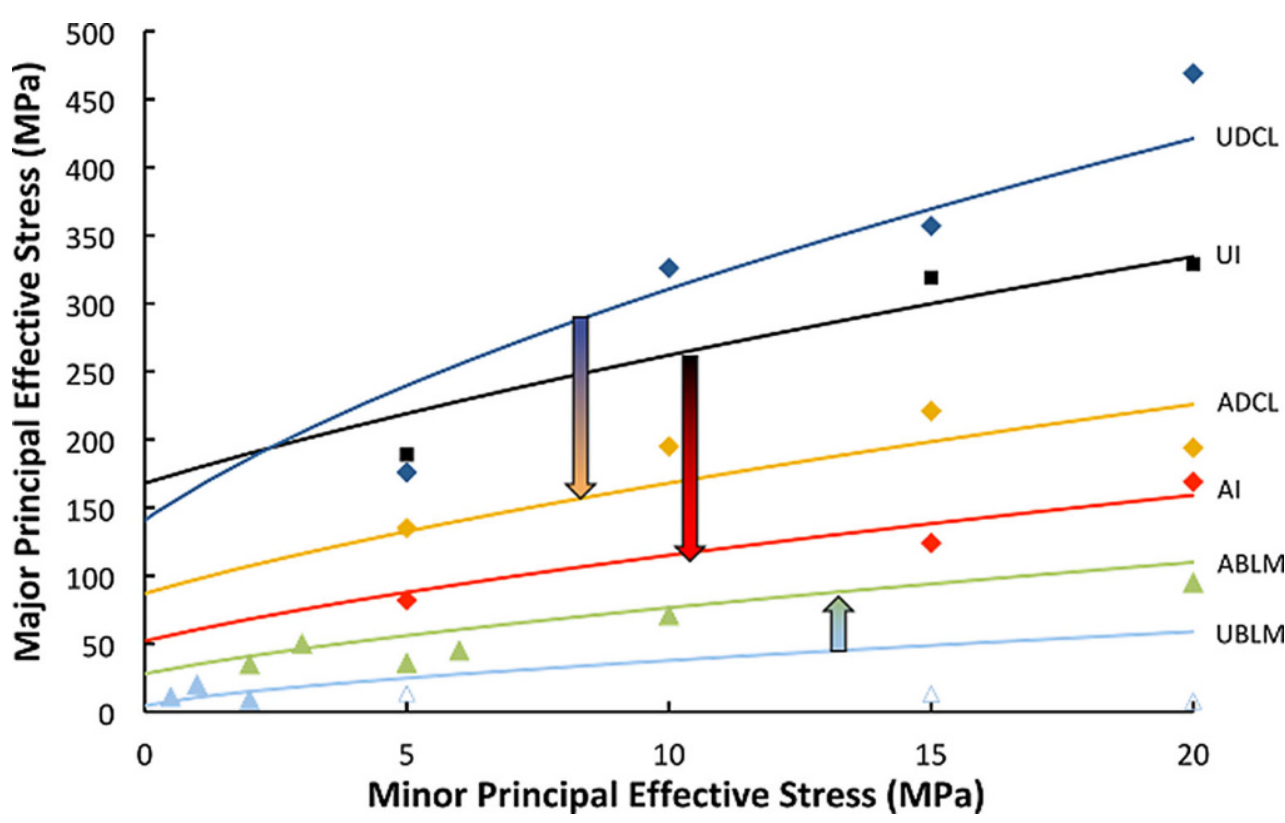

strength, the rocks near the wellbore can either compact, thereby causing large deformations, or be induced to tensile failure, possibly leading to instability (Fig. 9). Tunnelling will induce similar stress changes by inducing zones of increased and decreased stress at the tunnel face, crown, sides and invert, and further changes to effective stress will occur if the rock masses are dewatered during excavation. What is important to consider is that depending on the texture, porosity and alteration, different rock units will respond differently to these induced stresses, depending on the magnitude of the induced stresses compared to the strength.

[17] show that altered volcanic and volcano-sedimentary rocks contain clay minerals, such as smectites and zeolites, which can lead to significant swelling potential. They suggest that simple tests, such as the ethylene glycol durability index, can be useful to identify rocks with potential for swelling, which could then be further tested using the oedometer swelling test to estimate swelling pressure.

The rapidly changing lithologies, often resulting in weak, soft lithologies adjacent to strong, stiff lithologies can lead to various design and construction issues, including those associated with mixed-face and mixed-wall conditions, such as heterogeneous deformation, blocky ground, and stress concentration in strong, stiff rock masses. While swelling and squeezing are clear challenges in weak, porous and altered volcanic rocks, spalling and strain burst are also key challenges in strong, massive volcanic rocks at high depth depending on stress magnitude and stress ratios, as observed at the Olmos tunnel in Peru [18]. Particularly relevant to volcanic rock masses is their commonly layered nature (Fig. 2), which can result in layer buckling and rock fall under low stress conditions, or buckling and unpredictable dynamic release under high stress [19].

[16] demonstrated that geothermal system exploitation can sufficiently disturb the induced stresses through drilling, fluid extraction and injection that, depending on their 

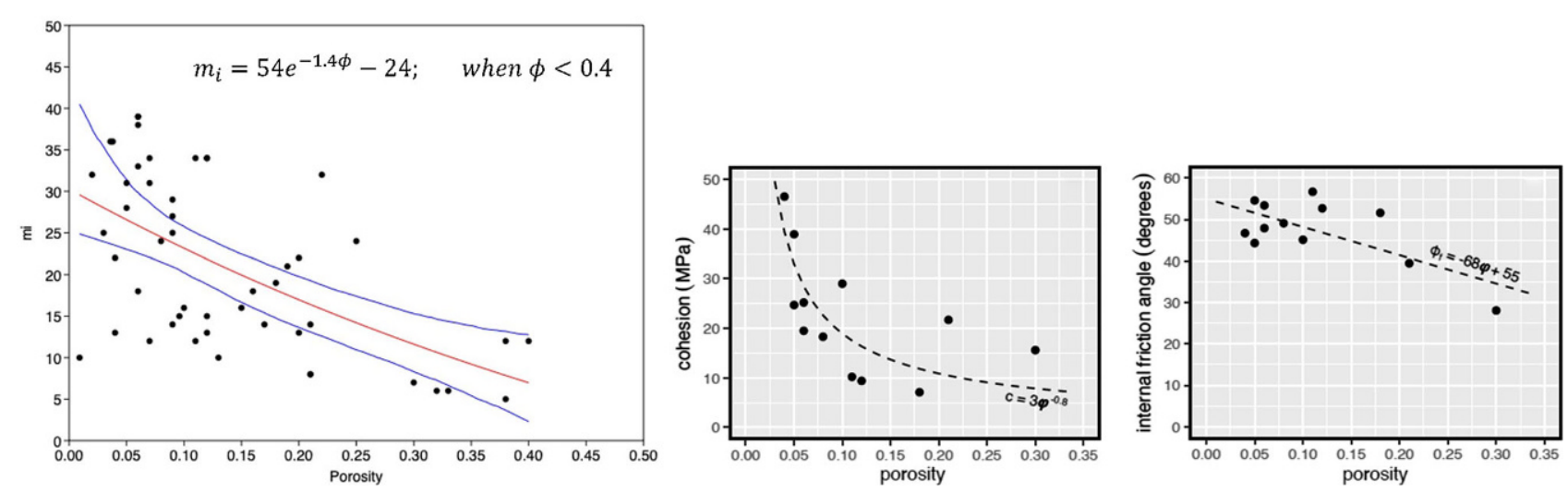

Fig. 8: Transfer functions with porosity for: a mi with mean function (red) and 95\% confidence interval (b/ue) [14]; b cohesion; c friction angle [13]

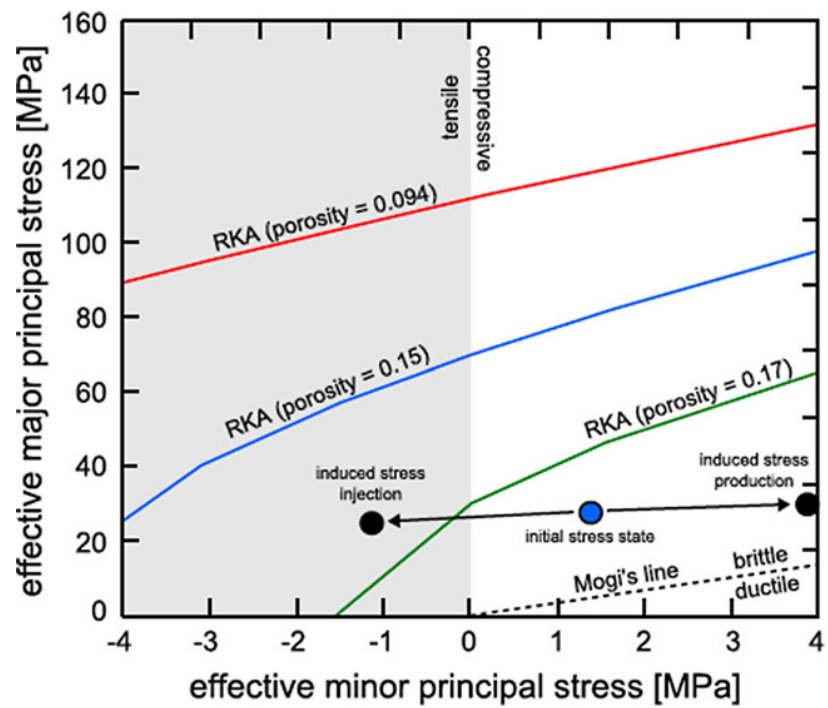

Fig. 9: Principal stress plot showing the in-situ stresses in a well at $2200 \mathrm{~m}$ depth compared to the failure criteria for Rotokawa andesite samples with porosities of $0.096,0.151$, and 0.178 . Initial stress state represents the undisturbed reservoir conditions; reinjection and extraction induced stresses represent the perturbed reservoir stresses resulting from changes in pore pressures during reservoir utilisation [16]. Analogies can be made to induced stresses in tunnel excavation

\section{Site Investigation and Design in Volcanic Rocks and Rock Masses}

[20] highlighted many lessons learned from the Majes tunnelling project in Peru, and suggest that a qualified geologist should be involved in the site investigation to correctly identify the different lithologies and their associated negative behaviours. [21] also highlight that careful site investigation is needed to determine as closely as possible the different rock and rock mass types that will be encountered by the tunnel.

As demonstrated in the previous sections, volcanic rocks and rock masses are highly variable, in particular with respect to macro texture, porosity, and composition. Laboratory experiments must be carefully planned and undertaken to characterise as many of the anticipated lithologies as possible since empirical and published values cannot capture this variability. The work regarding the impact of porosity on mechanical parameters provides a means for estimating these parameters using simple porosity measurements [20]. also show the potential for originally dry units to be wetted during and after excavation, with resulting slaking and swelling. They suggest that all lithologies should be tested for swelling and slaking, regardless of expected water ingress.

[21] show that tunnelling in volcanic rock masses requires modification to existing techniques to take into consideration the particular characteristics associated with volcanic processes. For example, rock mass classification, such as the $\mathrm{Q}$ system, needs to be adjusted to reduce the impact of columnar jointing in basalt lava, and transitioning away from rock mass classification in highly porous or poorly lithified rock masses, such as scoria and unwelded tuff. [22] also conclude that rock mass classification systems should only be used with caution in these rock masses, and that while many rock units are not sampleable for laboratory testing, they must be taken into account in the design. [23] also say that rock mass classification schemes need to be modified for volcanic rock masses, and that advance borings in the tunnel face are an important tool for reducing the risk of encountering unexpected poor geological conditions.

Adaptable tunnelling methods, whether conventional or mechanised, are best suited to the highly variable geological conditions as highlighted by [24]. These methods must be capable of mitigating behaviour ranging from high plastic deformations to dynamic brittle rupture, often within close succession. Support types also need to consider the wide range of expected behaviour, particular the potential for high pressures on the lining.

Funding. Open access funding provided by Montanuniversität Leoben.

Open Access This article is licensed under a Creative Commons Attribution 4.0 International License, which permits use, sharing, adaptation, distribution and reproduction in any medium or format, as long as you give appropriate credit to the original author(s) and the source, provide a link to the Creative Commons licence, and indicate if changes were made. The images or other third party material in this article are included in the article's Creative Commons licence, unless indicated otherwise in a credit line to the material. If material is not included in the article's Creative Commons licence and your intended use is not permitted by statutory regulation or exceeds the permitted use, you will need to obtain permis- 
sion directly from the copyright holder. To view a copy of this licence, visit http://creativecommons.org/licenses/by/4.0/.

\section{References}

1. Diederichs, M.S.; Kaiser, P.K.; Eberhardt, E.: Damage initiation and propagation in hard rock during tunnelling and the influence of near-face stress rotation, Int J Rock Mech Min., 41 (2004), pp 785-812, https://doi.org/10.1016/j.ijrmms.2004.02.003

2. Heap, M.J.; Baumann, T.; Gilg, H.A.; Kolzenburg, S.; Ryan, A.G.; Villeneuve, M.; Russell, J.K.; Kennedy, L.A.; Rosas-Carbajal, M.; Clynne, M.A.: Hydrothermal alteration can result in pore pressurization and volcano instability Geology, 49 (2021), pp 1348-1352, https://doi.org/10.1130/g49063.1

3. Kennedy, B.M.; Farquhar, A.; Hilderman, R.; Villeneuve, M.C.; Heap, M.J.; Mordensky, S.; Kilgour, G.; Jolly, A.; Christenson, B.; Reuschlé, T.: Pressure Controlled Permeability in a Conduit Filled with Fractured Hydrothermal Breccia Reconstructed from Ballistics from Whakaari (White Island), New Zealand. Geosciences, 10 (2020), 138, https://doi.org/10.3390/geosciences 10040138

4. Cumming, W.: Resource conceptual models of volcano-hosted geothermal reservoirs for exploration well targeting and resource capacity assessment: Construction, Pitfalls and Challenges, Geothermal Research Council Transactions, 40 (2016), pp 623-638

5. Garden, T.O.; Chambefort, I.; Gravley, D.M.; Deering, C.D.; Kennedy, B.M.: Reconstruction of the fossil hydrothermal system at Lake City caldera, Colorado, U.S.A.: Constraints for caldera-hosted geothermal systems, J Volcanol Geoth Res., 393 (2020), 106794, https://doi. org/10.1016/j.jvolgeores.2020.106794

6. Heap, M.J.; Violay, M.E.S.: The mechanical behaviour and failure modes of volcanic rocks: a review, B Volcanol, 83 (2021), https://doi. org/10.1007/s00445-021-01447-2

7. Heap, M.J.; Villeneuve, M.; Albino, F; Farquharson, J.I.; Brothelande, E.; Amelung, F.; Got, J.-L.; Baud, P.: Towards more realistic values of elastic moduli for volcano modelling, J Volcanol Geoth Res, 390 (2020), 106684, https://doi.org/10.1016/j.jvolgeores.2019. 106684

8. Wyering, L.; Villeneuve, M.; Wallis, I.; Siratovich, P.; Kennedy, B.; Gravley, D.; Cant, J.: Mechanical and physical properties of hydrothermally altered rocks, Taupo Volcanic Zone, New Zealand, J Volcanol Geoth Res, 2014, pp 76-93, https://doi.org/10.1016/j. jvolgeores.2014.10.008

9. Villeneuve, M.; Kennedy, B.; Gravley, D.; Mordensky, S.; Heap, M. J.; Siratovich, P.; Wyering, L.; Cant, J.: Characteristics of altered volcanic rocks in geothermal reservoirs, In: Rock Mechanics for Natural Resources and Infrastructure Development-Proceedings of the 14th International Congress on Rock Mechanics and Rock Engineering, ISRM 2019, Foz do Iguassu, Brazil, 2020, pp 3120-3127

10. Cant, J.L.; Siratovich, P.A.; Cole, J.W.; Villeneuve, M.C.; Kennedy, B.M.: Matrix permeability of reservoir rocks, Ngatamariki geothermal field, Taupo Volcanic Zone, New Zealand Geotherm Energy, 6 (2018), 2 https://doi.org/10.1186/s40517-017-0088-6

11. Hoek, E.; Brown, E.: Practical estimates of rock mass strength, Int J. Rock Mech. Min. Sci., 34(8) (1997), https://doi.org/10.1016/S13651609(97)80069-X
12. Read, S.; Richards, L.: A Comparative Study of mi, the Hoek-Brown Constant for Intact Rock Material. In: 12th ISRM International Congress on Rock Mechanics, Beijing, China, 18-21 October, 2011

13. Villeneuve, M.; Heap, M.J.: Calculating the cohesion and internal friction angle of volcanic rocks and rock masses, Volcanica, 4(2) (2021), https://doi.org/10.30909/vol.04.02.279293

14. Villeneuve, M.; Heap, M.J.; Schaefer, L.N.: Defining the Hoek-Brown Constant $\mathrm{m}$ i for Volcanic Lithologies. In: 5th International Workshop on Rock Mechanics and Engineering Geology in Volcanic Fields (RMEGV2021), Sept. 9-11. , Fukuoka, Japan, 2021

15. Mordensky, S.P.; Villeneuve, M.C.; Farquharson, J.I.; Kennedy, B.M.; Heap, M.J.; Gravley, D.M.: Rock mass properties and edifice strength data from Pinnacle Ridge, Mt. Ruapehu, New Zealand, J Volcanol Geoth Res, 367 (2018), pp 46-62, https://doi.org/10.1016/ j.jvolgeores.2018.09.012

16. Siratovich, P.A.; Heap, M.J.; Villeneuve, M.C.; Cole, J.W.; Kennedy, B.M.; Davidson, J.; Reuschlé, T.: Mechanical behaviour of the Rotokawa Andesites (New Zealand): Insight into permeability evolution and stress-induced behaviour in an actively utilised geothermal reservoir, Geothermics, 64 (2016), pp 163-179, https://doi.org/ 10.1016/j.geothermics.2016.05.005

17. Galera, J.; Paredes, M.; Menchero, C.; Pozo, V.: Rock Engineering and Rock Mechanics: Structures in and on Rock Masses, 2014, pp 841-846, https://doi.org/10.1201/b16955-144

18. Diederichs, M.S.: Early assessment of dynamic rupture hazard for rockburst risk management in deep tunnel projects., J S Afr I Min Metall, 118 (2018), pp 193-204, https://doi.org/10.17159/2411-9717/ 2018/v118n3a1

19. Diederichs, M.S.: Challenges in tunnelling through layered rockmasses. In: ISRM International SymposiumEurock 2020-Hard Rock EngineeringTrondheim, Norway, 14-19 June, 2020

20. Ceriani, G.; Nord, G.: Majes Project: Geological Conditions and Construction. In: 5th ISRM Congress, April 10-15, 1983

21. Rodrigues, C.; Grøv, E.; Prada, S.: Tunnells In Volcanic Environment Experiences From Projects In Madeira Island, Iceland And Faroe Islands, In: ISRM International Symposium-EUROCK 2002, November 25-27, 2002

22. Vibert, C.; Azeb, A.; lanos, S.; Mine, E.: Unusual Rock Mechanics Challenges Encountered During Construction ofa Large Dam, In: ISRM International Symposium-8th Asian Rock Mechanics Symposium, October 14-16, 2014, pp 108-120

23. Kamemura, K.; Kurahashi, T.; Okazaki, K.; Yamazaki, S.; Murayama, $\mathrm{H}$.: On the effective rock mass classification using advancing boring in NATM, In: ISRM International SymposiumEurock 2020-Hard Rock EngineeringTrondheim, Norway, 14-19 June, 2020

24. Santamarta-Cerezal, J.C.; Hernández, L.E.; Rodríguez-Losada, J.A.: Volcanic dikes engineering properties for storing and regulation of the underground water resources in volcanic islands, In: Volcanic Rock Mechanics Rock Mechanics and Geo-engineering in Volcanic Environments, May 31-June 1, 2010, pp 95-98

Publisher's Note. Springer Nature remains neutral with regard to jurisdictional claims in published maps and institutional affiliations. 